\title{
HUBUNGAN ASUPAN ENERGI, PROTEIN, STATUS GIZI TERHADAP PPRESTASI BELAJAR MAHASISWA DI POLITEKNIK KESEHATAN KEMENKES TASIKMALAYA
}

\author{
Deris Aprianty \\ Dosen Jurusan Gizi Poltekkes Kemenkes Tasikmalaya
}

\begin{abstract}
Abstrak
Selama 2 dekade terakhir, ukuran paling popular memulai kemajuan pembangunan SDM ialah dengan Human Development Index (HDI) yang dikembangkan oleh UNDP. HDI merupakan gambaran keadaan manusia ditinjau dari aspek kesehatan, pendidikan, dan ekonomi. Dalam Human Development Report 2001, selain HDI dimunculkan indeks baru yaituTechnology Achievement Index (TAl). Indeks baru ini untuk menunjukkan kemajuan teknologi SDM yang berkualitas tinggi diperlukan untuk memanfaatkan dan mengembangkan kemajuan teknologi yang sedang terjadi. (Khomsan, 2012). Tujuan penelitian untuk mengetahui hubungan asupan gizi, protein dan status gizi terhadap prestasi belajar mahasiswa Poltekkes Kemenkes Tasikmalaya. Studi epidemiologi observasi menggunakan desain cross sectional, menggunakan analisis kuantitatif. Subjek penelitian adalah mahasiswa Poltekkes Kemenkes Tasikmalaya. Jumlah sampel sebanyak 100 mahasiswa. Data yang dikumpulkan adalah data karakteristik responden, data konsumsi dengan formulir recall 24 jam dan pengukuran status gizi. Hasil penelitian menggambarkan asupan energi yang baik sebesar $85 \%$, asupan protein yang baik sebesar $80 \%$, status gizi baik $63 \%$ dan mahasiswa berprestasi sebesar $44 \%$. Terdapat hubungan yang signifikan antara asupan energi dengan status gizi, asupan protein dengan status gizi dan status gizi dengan prestasi belajar pada mahasiswa Poltekkes Kemenkes Tasikmalaya. Terdapat hubungan yang signifikan antara asupan energy, asupan protein dan status gizi dengan prestasi belajar pada mahasiswa Poltekkes Kemenkes Tasikmalaya.
\end{abstract}

Kata kunci: asupan, status gizi, prestasi belajar.

\begin{abstract}
Abstrack
Over the past 2 decades, the most popular size for start construction progress of human resources is with a Human development Index (HDI) developed by UNDP. HDI is the picture of the human condition in term of health, education and economics. In the human development report 2001, in additional to HDI raise a new index called The Technology Achievment Index (TAl). The new indeks is to demonstrate that technological advances of high quality human resources needed to be able to utilize and develop the technological advances that are happening (Komsan, 2012). Knowing the relathionship of enery protein intake, nutritional status and learning achievement of student at Healt Polytechnic Healt Ministry Tasikmalaya. The type of research is observational epidemiological study using cross sectional design, using quantitative analysis. The subject were students of Healt Polytechnic Healt Ministry Tasikmalaya. The study was conducted in May to October 2014 with total sample 100 students. The data collected are characteristics data of respondent, consumption data from Recall 24 hours and nutritional status measurement. A good overview of energy intake are $85 \%$, protein intake are $80 \%, 63 \%$ for good nutritional status and $44 \%$ for student learning achievement. There is a significant relathionship between energy intake and nutritional status of student at Healt Polytechnic Healt Ministry Tasikmalaya. There is a significant relathionship between protein intake and nutritional status of student at Healt Polytechnic Healt Ministry Tasikmalaya. There is a significant relathionship between nutritional status and learning achievement of student at Healt Polytechnic Healt Ministry Tasikmalaya. There is a significant relation between enery protein intake, nutritional status and learning achievement of student at Healt Polytechnic Healt Ministry Tasikmalaya.
\end{abstract}

Keywords : Intake, nutritional status, learning achievment. 
Deris Aprianty, Poltekkes Tasikmalaya; asupan, status gizi, prestasi belajar.

\section{PENDAHULUAN}

Selama 2 dekade terakhir, ukuran paling popular untuk memulai kemajuan pembangunan SDM ialah dengan Human Development Index (HDI) yang dikembangkan oleh UNDP. HDI merupakan gambaran mengenai keadaan manusia ditinjau dari aspek kesehatan, pendidikan, dan ekonomi. Dalam Human Development Report 2001, selain HDI dimunculkan suatu indeks baru yang disebut Technology Achievement Index (TAI). Indeks baru ini untuk menunjukkan bahwa kemajuan teknologi SDM yang berkualitas tinggi diperlukan untuk dapat memanfaatkan dan mengembangkan kemajuan teknologi yang sedang terjadi. (Khomsan, 2012)

Tingkat pendidikan masyarakat menentukan tingkat kemajuan teknologi suatu negara sebagaimana ditunjukkan dalam TAI. Rata-rata lama pendidiakan menyebabkan makin tinggi tingkat TAI.Salahsatu faktor yang menetukan keberhasilan pendidikan adalah keadaan kesehatan dan gizi anak sekolah.(Khomsan, 2012)

Keberhasilan program kesehatan yang berdampak pada peningkatan usia hidup dan kesadaran orang tua tentang pentingnya pendidikan dasar membawa positif yaitu semakin besarnya proporsi anak yang menempuh pendidikan formal. Akses pendidikan yang semakin baik perlu ditunjang oleh kondisikesehatan dan gizi yang cukup sehingga anak-anak usia sekolah dapat memaksimalkan potensi untuk meraih pencapaian akademik yang maksimal(Khomsan, 2012). Masalah gizi yang terjadi di negara-negara maju dan berkembang bukan saja masalah kekurangan gizi saja tetapi juga masalahgiziberlebih. Masalah gizi lebih baru muncul dipermukaan pada tahun-tahun terakhir PJP 1, yaitu pada awal tahun 1990-an. Peningkatan pendapatan pada kelompok masyarakat tertentu, terutama diperkotaanmenyebabkan perubahan dalam gaya hidup, terutama dalam pola makan. Pola makan tradisional yang tadinya tinggi karbohidrat, rendah serat dan tinggi lemak sehingga menggeser mutu makanan kearah tidak seimbang. Perubahan pola makanan ini dipercepat oleh makin kuatnya arus budaya asing yang disebabkan oleh kemajuan teknologi informasi dan globalisasi ekonomi. Pola makan tersebut dapat berakibat semakin banyaknya penduduk golongan tertentu mengalami gizi lebih berupa kegemukan atau obesitas. (Almatsier, 2001)

Kurang gizi akan menyebabkan kegagalan pertumbuhan fisik dan perkembangan kecerdasan, menurunkan daya tahan, meningkatkan kesakitan dan kematian (Achmad, 2000). Dalam Widyakarya Nasional Pangan dan Gizi (2012) disebutkan bahwa pada anak usia sekolah kekurangan gizi akan mengakibatkan anak menjadi lemah, cepat lelah dan sakit-sakitan sehingga anak seringkali absen serta mengalami kesulitan mengikuti dan memahami pelajaran.

Keadaan kesehatan gizi tergantung dari tingkat konsumsi.Tingkat konsumsi ditentukan oleh kualitas hidangan. Kualitas hidangan menunjukkan semua zat gizi yang diperlukan tubuh di dalam susunan hidangan dan perbandingan yang satu terhadap yang lain. Susunan hidangan yang memenuhi kebutuhan tubuh, baik kualitas maupun kuantitas, maka tubuh akan mendapatkan kondisi kesehatan gizi yang sebaik-baiknya (Sediaoetama, 2002)

Keadaan gizi akan mempengaruhi kemampuan anak dalam mengikuti pelajaran di sekolah dan akan mempengaruhi prestasi belajar, Penelitian kaitan indeks prestasi dengan status gizi anak yang dilakukan di Kabupaten Nabire oleh Wilma (2006) menemukan bahwa semakin rendah status gizi siswa semakin rendah pula nilai prestasi mereka. Cara untuk menilai kualitas seorang anak diantaranya adalah dengan menilai prestasi belajar disekolah. Prestasi yang dicapai menunjukan hasil dari proses belajar. Prestasi belajar anak didik dipakai sebagai ukuran untuk mengetahui sejauh mana mereka dapat menguasai pelajaran yang sudah diajarkan atau dipelajari.

Politeknik Kesehatan Kemenkes Tasikmalaya merupakan salah satu perguruan tinggi kesehatan negeri di 
Deris Aprianty, Poltekkes Tasikmalaya; asupan, status gizi, prestasi belajar.

Tasikmalaya yang menghasilkan tenaga kesehatan yang terdiri dari perawat, bidan, perawat gigi, ahli gizi, perekam medik dan tenaga farmasi. Berdasarkan informasi di atas penulis tertarik meneliti bagaimana hubungan

\section{METODE PENELITIAN}

Jenis penelitian ini adalah penelitian observasional dengan pendekatan kuantitatif dengan rancangan cross sectional. Lokasi penelitian di Politeknik Kesehatan Kemenkes Tasikmalaya dan waktu penelitian dimulai pada bulan Oktober tahun 2014. Populasi penelitian adalah seluruh mahasiswa Politeknik Kesehatan Kemenkes Tasikmalaya wilayah Tasikmalaya dengan sampel sebanyak 100 orang masing-masing jurusan 20 orang. Mahasiswa dengan kriteria inklusi: mahasiswa tingkat dua dan tiga, bersedia mengikuti penelitian. Kriteris eksklusi: mahasiswa yang mengidap penyakit kronis, missal: TBC, anemia aplastik dll., pada saat penelitian tidak hadir. Pengambilan sampel dari masing-masing jurusan dilakukan dengan menggunakan metode proportional random sampling tanpa membedakan jenis kelamin. Variabel bebas (independent) adalah asupan energi proteinsedangkan variabel terikatnya (dependent) adalah prestasi belajar dan

\section{HASIL PENELITIAN}

Poltekkes Kemenkes Tasikmalaya teridiri dari 6 jurusan yaitu Keperawatan, Kebidanan, Kesehatan Gigi, Gizi, Perekam Medis dan asupan energi protein terhadapstatus gizi terhadap prestasi belajar mahasiswanya dimana dilain pihak mahasiswa tersebut berada dilingkup pendidikan kesehatan.

variable antaranya adalah status gizi. Kuesioner untuk data karakteristik responden, alat pengukur berat badan dan tinggi badan, dan Kartu Hasil Studi Asupan energi dan protein menggunakan formulir recall 24 jam. Analisis data meliputi univariat dan bivariat Fisher exact menggunakan SPSS. Asupan energi dan protein menggunakan program nutrisurvey.

Etika penelitian sebelum pengambilan data, kepada responden dijelaskan maksud dan tujuan pengambilan data serta dijelaskan bahwa penelitian ini bersifat observasi. Intervensi apapun tidak dilakukan kepada responden penelitian. Dijelaskan juga tentang data-data apa saja yang akan dikumpulkan dan bahwa data-data beserta identitas responden akan dijaga kerahasiaannya. Bukti kesediaan mengikuti penelitian ini, responden penelitian diminta menandatangani lembar persetujuan (informed consent) yang telah disiapkan sebelumnya.

Informatika Kesehatan (PIKES) dan Farmasi dan terdiri dari program DIII dan DIV.

Tabel 2. Karakteristik Umur Subjek Penelitian

\begin{tabular}{cccc}
\hline No & Kelompok Umur & $\mathbf{n}$ & $\%$ \\
\hline 1 & 19 Tahun & 11 & 11,0 \\
2 & 20 Tahun & 64 & 64,0 \\
3 & 21 Tahun & 25 & 25,0 \\
\hline & Total & 100 & 100,0 \\
\hline
\end{tabular}

Umur subjek penelitian sebanyak $64 \%$ adalah berumur 20 tahun, 25\% 21 tahun dan $11 \%$ berumur 19 tahun. 
Deris Aprianty, Poltekkes Tasikmalaya; asupan, status gizi, prestasi belajar.

Tabel 2. Jumlah Mahasiswa Poltekkes Kemekes Tasikmalaya Tahun2014

\begin{tabular}{|c|c|c|c|c|c|c|}
\hline No & Prodi / Jurusan & Tingkat & Program & $\mathbf{L}$ & $\mathbf{P}$ & Jumlah \\
\hline \multirow[t]{9}{*}{1} & Jurusan Keperawatan & & & & & \\
\hline & Prodi Keperawatan Tasikmalaya & I & Jalum A & 18 & 23 & 41 \\
\hline & & & Jalum B & 17 & 24 & 41 \\
\hline & & & Jalum C & 18 & 22 & 40 \\
\hline & & II & Jalum A & 21 & 18 & 39 \\
\hline & & & Jalum B & 23 & 17 & 40 \\
\hline & & & Jalum C & 20 & 20 & 40 \\
\hline & & III & Jalum A & 23 & 17 & 40 \\
\hline & & & Jalum B & 17 & 23 & 40 \\
\hline \multirow[t]{10}{*}{2} & Jurusan Kebidanan & & & & & \\
\hline & a. Prodi Kebidanan Tasikmalaya & I & Jalum A & & 25 & 25 \\
\hline & & & Jalum B & & 30 & 30 \\
\hline & & II & Jalum A & & 25 & 25 \\
\hline & & & Jalum B & & 24 & 24 \\
\hline & & III & Jalum A & & 25 & 25 \\
\hline & & & Jalum B & & 24 & 24 \\
\hline & b. Prodi D IV Kebidanan Klinik & & & & & \\
\hline & $\begin{array}{l}\text { Tasikmalaya } \\
\text { c. Prodi D IV Kebidanan Klinik }\end{array}$ & o Tahun & & & 40 & 40 \\
\hline & Tasikmalaya & Apr-13 & & & 40 & 40 \\
\hline \multirow[t]{8}{*}{3} & Jurusan Keperawatan Gigi & & & & & \\
\hline & a. Prodi Keperawatan Gigi & I & Jalum & 8 & 37 & 45 \\
\hline & & II & Jalum A & 6 & 30 & 36 \\
\hline & & & Jalum B & 6 & 28 & 34 \\
\hline & & III & Jalum & 11 & 29 & 40 \\
\hline & b. Prodi D IV Keperawatan Gigi & 0 Tahun & & 8 & 18 & 26 \\
\hline & c. Prodi D IV Keperawatan Gigi & Apr-13 & Kelas A & 8 & 30 & 38 \\
\hline & & & Kelas B & 6 & 25 & 31 \\
\hline \multirow[t]{4}{*}{4} & Jurusan Gizi & & & & & \\
\hline & Prodi Gizi Tasikmalaya & I & Jalum & 5 & 37 & 42 \\
\hline & & II & Jalum & 4 & 36 & 40 \\
\hline & & III & Jalum & 9 & 30 & 39 \\
\hline \multirow[t]{4}{*}{5} & Jurusan Pikes & & & & & \\
\hline & Prodi Pikes Tasikmalaya & I & Jalum & 7 & 38 & 45 \\
\hline & & II & Jalum & 8 & 31 & 39 \\
\hline & & III & Jalum & 15 & 25 & 40 \\
\hline \multirow[t]{2}{*}{6} & Jurusan Farmasi & I & Jalum & 5 & 39 & 44 \\
\hline & JUMLAH & & & 263 & 597 & 860 \\
\hline
\end{tabular}

Sumber : Laporan Akademik Tahun 2014

Penelitian ini dilaksanakan di enam tempat yang berbeda yaitu di Jurusan Gizi, Gigi, PIKES, Keperawatan, Farmasi dan
Kebidanan pada Politeknik Kesehatan Kemenkes Tasikmalaya yang berada di wilayah Tasikmalaya. 
Deris Aprianty, Poltekkes Tasikmalaya; asupan, status gizi, prestasi belajar.

Tabel 3. Karakteristik Jenis Kelamin Subjek Penelitian

\begin{tabular}{clrc}
\hline No & Jenis Kelamin & $\mathbf{n}$ & $\%$ \\
\hline 1 & Laki-laki & 17 & 17,0 \\
2 & Perempuan & 83 & 83,0 \\
\hline & Total & 100 & 100,0 \\
\hline
\end{tabular}

Jenis kelamin subjek penelitian sebanyak 17\% laki laki dan $83 \%$ adalah berjenis kelamin perempuan.

Tabel 4. Karakteristik Pekerjaan Ayah Subjek Penelitian

\begin{tabular}{clcc}
\hline No & Pekerjaan Ayah & $\mathbf{n}$ & $\%$ \\
\hline 1 & PNS & 38 & 38,0 \\
2 & Wiraswasta & 62 & 62,0 \\
\hline & Total & 100 & 100,0 \\
\hline
\end{tabular}

Jenis pekerjaan ayah sebanyak $62 \%$ adalah sebagai wiraswasta dan $38 \%$ sebagai PNS.

Tabel 5. Karakteristik Pekerjaan Ibu Subjek Penelitian

\begin{tabular}{cccc}
\hline No & Karakteristik Pekerjaan Ibu & $\mathbf{n}$ & $\%$ \\
\hline 1 & Ibu Rumah Tangga & 54 & 54,0 \\
2 & PNS & 42 & 42,0 \\
3 & Wiraswasta & 4 & 4,0 \\
\hline & Total & 100 & 100,0 \\
\hline
\end{tabular}

Jenis pekerjaan ibu sebanyak $54 \%$ adalah sebagai ibu rumah tangga dan $42 \%$ sebagai PNS dan $4 \%$ wiraswasta.

Tabel 6. Asupan Energi

\begin{tabular}{|c|c|c|c|c|c|c|c|}
\hline \multicolumn{4}{|c|}{ Kriteria } & \multirow{3}{*}{ Total } & \multirow{3}{*}{$\begin{array}{l}\text { Rata-Rata } \\
\text { (kkal/hari) }\end{array}$} & \multirow{3}{*}{$\begin{array}{c}\text { Asupan } \\
\text { Terendah } \\
\text { (kkal/hari) }\end{array}$} & \multirow{3}{*}{ SD } \\
\hline \multicolumn{2}{|c|}{ Baik } & \multicolumn{2}{|c|}{ Cukup } & & & & \\
\hline $\mathbf{n}$ & $\%$ & & $\%$ & & & & \\
\hline 85 & 85 & 15 & 15 & 100 & 2510 & 2120 & $2120 \pm 2510$ \\
\hline
\end{tabular}

Rata-rata asupan energy adalah $2510 \mathrm{kkal} / \mathrm{hari}$. Sebanyak $90 \%$ kategori baik dan 30\% kategori cukup.Asupan terendah adalah $2120 \mathrm{kkal} / \mathrm{hari}$.

Tabel 7. Asupan Protein

\begin{tabular}{|c|c|c|c|c|c|c|c|}
\hline \multicolumn{4}{|c|}{ Kriteria } & \multirow{3}{*}{ Total } & \multirow{3}{*}{$\begin{array}{c}\text { Rata-Rata } \\
\text { (Gram) }\end{array}$} & \multirow{3}{*}{$\begin{array}{c}\text { Asupan } \\
\text { Terendah } \\
\text { (Gram) }\end{array}$} & \multirow{3}{*}{ SD } \\
\hline \multicolumn{2}{|c|}{ Baik } & \multicolumn{2}{|c|}{ Cukup } & & & & \\
\hline $\mathbf{n}$ & $\%$ & & $\%$ & & & & \\
\hline 80 & 80 & 20 & 20 & 100 & 58 & 45 & $45 \pm 58$ \\
\hline
\end{tabular}

Rata-rata asupan protein adalah 58 gram. Sebanyak $80 \%$ kategori baik dan $20 \%$ kategori cukup.Asupan terendah adalah 45 gram. 
Deris Aprianty, Poltekkes Tasikmalaya; asupan, status gizi, prestasi belajar.

Tabel 8. Karakteristik Status Gizi

\begin{tabular}{cccc}
\hline No & Karakteristik Status Gizi & N & $\%$ \\
\hline 1 & Kurang & 24 & 14,0 \\
2 & Normal & 63 & 63,0 \\
3 & Lebih & 13 & 13,0 \\
\hline & Total & 100 & 100,0
\end{tabular}

Sebanyak $\overline{63 \% \text { subjek mempunyai status gizi normal, } 13 \% \text { status gizi lebih dan }}$ sebanyak $10 \%$ dengan status gizi kurang.

Tabel 9. Karakteristik Status Gizi

\begin{tabular}{cccc}
\hline No & Karakteristik Prestasi Belajar & N & $\%$ \\
\hline 1 & Berprestasi & 44 & 44,0 \\
2 & Tidak berprestasi & 56 & 56,0 \\
\hline & Total & 100 & 100,0 \\
\hline
\end{tabular}

Sebanyak $44 \%$ subjek penelitian berprestasi dan sebanyak $56 \%$ tidak berprestasi.

Tabel 10. Hubungan Asupan Energi Dan Status Gizi

\begin{tabular}{|c|c|c|c|c|c|c|c|c|}
\hline \multirow{3}{*}{$\begin{array}{c}\text { Asupan } \\
\text { Energi }\end{array}$} & \multicolumn{4}{|c|}{ Status Gizi } & \multirow{2}{*}{\multicolumn{2}{|c|}{ Total }} & \multirow{3}{*}{$\mathrm{X}^{2}$} & \multirow{3}{*}{$P$ value } \\
\hline & \multicolumn{2}{|c|}{ Baik } & \multicolumn{2}{|c|}{ Tidak Baik } & & & & \\
\hline & $\mathbf{N}$ & $\%$ & $\mathbf{n}$ & $\%$ & $\mathbf{n}$ & $\%$ & & \\
\hline Baik & 60 & 95,2 & 25 & 67,6 & 85 & 85 & 43,81 & 0,00 \\
\hline Cukup & 3 & 4,8 & 12 & 32,4 & 15 & 15 & & \\
\hline Total & 63 & 100 & 37 & 100 & 100 & 100 & & \\
\hline
\end{tabular}

Hasil uji hubungan antara asupan energi dan status gizi menghasilkan nilai signifikasi sebesar 0,00. Nilai tersebut lebih besar dari dari nilai alpha sebesar 0,05 maka Ho ditolak.
Dengan demikian dapat disimpulkan bahwa ada hubungan antara asupan energidengan status gizi.

Tabel 11. Hubungan Asupan Protein Dan Status Gizi

\begin{tabular}{|c|c|c|c|c|c|c|c|c|}
\hline \multirow{3}{*}{$\begin{array}{l}\text { Asupan } \\
\text { Protein }\end{array}$} & \multicolumn{4}{|c|}{ Status Gizi } & \multirow{2}{*}{\multicolumn{2}{|c|}{ Total }} & \multirow{3}{*}{$x^{2}$} & \multirow{3}{*}{$P$ value } \\
\hline & \multicolumn{2}{|c|}{ Baik } & \multicolumn{2}{|c|}{ Tidak Baik } & & & & \\
\hline & $\mathbf{N}$ & $\%$ & $\mathbf{n}$ & $\%$ & $\mathbf{n}$ & $\%$ & & \\
\hline Baik & 55 & 87,3 & 25 & 67,5 & 80 & 80 & 45,77 & 0,00 \\
\hline Cukup & 8 & 12,7 & 12 & 32,5 & 20 & 20 & & \\
\hline Total & 63 & 100 & 37 & 100 & 100 & 100 & & \\
\hline
\end{tabular}

Hasil uji hubungan antara asupan protein dan status gizi menghasilkan nilai signifikasi sebesar 0,00 . Nilai tersebut lebih besar dari dari nilai alpha sebesar 0,05 maka Ho ditolak. Kesimpulannyabahwa ada hubungan antara asupan protein dengan status gizi.

Tabel 12. Hubungan Antara Status Gizi Dan Prestasi Belajar

\begin{tabular}{|c|c|c|c|c|c|c|c|c|}
\hline \multirow{3}{*}{ Status Gizi } & \multicolumn{4}{|c|}{ Prestasi Belajar } & \multirow{2}{*}{\multicolumn{2}{|c|}{ Total }} & \multirow{3}{*}{$x^{2}$} & \multirow{3}{*}{$P$ value } \\
\hline & \multicolumn{2}{|c|}{ Baik } & \multicolumn{2}{|c|}{ Kurang } & & & & \\
\hline & $\mathbf{N}$ & $\%$ & $\mathbf{n}$ & $\%$ & $\mathbf{n}$ & $\%$ & & \\
\hline Baik & 40 & 90,9 & 23 & 41,1 & 63 & 63 & 57,00 & 0,00 \\
\hline Tidak Baik & 4 & 9,1 & 33 & 58,9 & 37 & 37 & & \\
\hline Total & 44 & 100 & 56 & 100 & 100 & 100 & & \\
\hline
\end{tabular}


Deris Aprianty, Poltekkes Tasikmalaya; asupan, status gizi, prestasi belajar.

Hasil uji hubungan antara status gizi dan prestasi belajar menghasilkan nilai signifikasi sebesar 0,00 . Nilai tersebut lebih besar dari

\section{PEMBAHASAN}

Hubungan antara asupan energl dan status gizi diteliti dengan Fisher dengan nilai signifikansi 0,05 dari hasil analisis diketahui ada hubungan yang bermakna antara asupan energl dengan status gizi. Hal ini sesuai dengan penelitian Sulasminingsih (2006) yang menyatakan ada hubungan antara asupan energi dengan status gizi di Bimomartani Sleman. Menurut Soekirman (2000) bahwa status gizi tidak baik disebabkan oleh asupan energi maupun protein yang tidak baik pula.Kebiasaan jajan merupakan salah satu yang menyebabkan konsumsi makanan baik energi, protein rendah.

Hasil penelitian Huwae (2005) sesuai dengan penelitian ini bahwa ada hubungan antara status gizi dengan prestasi belajar.Prestasi belajar dipengaruhi oleh faktor luar dari status gizi yaitu prasarana belajar dan pendekatan belajar. Sesuai dengan pendapat Syah (2001) bahwa secara garis besar faktor yang mempengaruhi prestasi belajar dibagi menjadi faktor internal dan eksternal. Faktor internal adalah semua faktor yang ada dalam diri siswa yang meliputi faktor fisik atau fisilologi dan faktor psikologis (intelegensia, status gizi, bakat, minat dan sikap) sedangkan faktor eksternal adalah semua faktor yang berada diluar siswa yang meliputi faktor lingkungan sosial dan faktor non sosial (faktor perbedaan individu dan faktor pendekatan belajar).

Menurut Soemantri (1978) apabila makanan yang dikonsumsi tidak cukup mengandung zat-zat gizi yang dibutuhkan

\section{KESIMPULAN}

Gambaran asupan energi yang baik pada mahasiswa Poltekkes Kemenkes Tasikmalaya adalah sebesar $85 \%$, dan cukup $15 \%$.Gambaran asupan protein yang baik pada mahasiswa Poltekkes Kemenkes Tasikmalaya adalah sebesar $80 \%$ dan cukup $20 \%$. Gambaran status gizi yang baik pada dari nilai alpha sebesar 0,05 maka Ho ditolak. Kesimpulannyabahwa ada hubungan antara status gizi dengan prestasi belajar.

dan keadaan ini berlangsung lama, akan menyebabkan perubahan metabolisme dalam otak. Hal ini akan mengakibatkan terjadinya ketidakmampuan otak untuk berfungsi normal. Pada keadaan lebih berat dan kronis, kekurangan gizi menyebabkan pertumbuhan terganggu, badan lebih kecil, jumlah sel dalam otak berkurang dan terjadi ketidakmatangan serta ketidaksempurnaan organisasi biokimia dalam otak. Keadaan ini berpengaruh terhadap perkembangan kecerdasan otak.Lebih jelasnya mekanisme status gizi hingga prestasi belajar rendah dimulai dari anak dengan status rendah yang disebabkan kurang asupan makanan. Diketahui makanan hanya mampu bertahan dalam lambung 6-8 jam, setelah itu lambung kosong karena sari-sari makanan telah diserap dan diedarkan keseluruh tubuh, maka untuk memenuhi kebutuhannya akan terjadi pemecahan glikogen, sehingga terjadi deplesi jaringan yang kemudian menyebabkan perubahan biokimia, perubahan fungsional dan perubahan anatomis tubuh.

Penelitian ini menyarankan supaya dilakukan penyuluhan atau edukasi gizi dengan tema pola hidup sehat yang lain untuk lebih meningkatkan atau mempertahankan kondisi status gizi mahasiswa. Perlu dilakukan penelitian lebih lanjut berkaiatan dengan variabellain yang mempengaruhi prestasi belajar, misalnya kadar haemoglobin karena status anemia akan mempengaruhi konsentrasi belajar mahasiswa.

mahasiswa Poltekkes Kemenkes Tasikmalaya adalah sebesar $63 \%$, kurang $24 \%$ dan lebih $13 \%$. Gambaran mahasiswa yang berprestasi sebanyak $44 \%$ dan tidak berprestasi sebanyak 56\%. Terdapat hubungan yang signifikan $(\rho=0,00)$ antara asupan energi dengan status gizi pada 
mahasiswa Poltekkes Kemenkes Tasikmalaya. Terdapat hubungan yang signifikan $(\rho=0,00)$ antara asupan protein dengan status gizi mahasiswa Poltekkes

\section{REFERENSI}

Almatsier. S., (2001). Prinsip Dasar Ilmu Gizi. Jakarta: PT Gramedia Pustaka Utama

Achmad, (2000). Penuntasan Masalh Gizi Kurang Gizi. In Widya Karya Nasional Pangan dan Gizi VI, Jakarta: Lembaga Ilmu Pengetahuan Indonesia

Husaini, Mahdin Anwar, dkk., (1989). Study Nutritional Anemia and Assesment of Information Compilation For Supporting and Formulating National Policy and Program. Direktorat Gizi Masyarakat. Depkes dan Puslitbang Gizi

Huwae, (2005). Hubungan Antara Status Gizi dan Kadar Hb Dengan Prestasi Belajar Murid SD Di Daerah Endemis Malaria. Program Sarjana UGM Inferences. Supplement: The INCAP Follow -up Study

Khomsan, A., (2012). Ekologi Masalah Gizi, Pangan Dan Kemiskinan. Bandung: Alfabeta
Kemenkes Tasikmalaya. Terdapat hubungan yang signifikan $(\rho=0,00)$ antara status gizi dengan status prestasi belajar mahasiswa Poltekkes Kemenkes Tasikmalaya.

Sediaoetama, (1996).IImu Gizi untuk Mahasiswa dan profesi di Indonesia. Dian Rakyat, Cetakan Kedua.

Sediaoetama, (2002). IImu Gizi untuk Mahasiswa dan profesi di Indonesia. Dian Rakyat, Cetakan Kelima.

Sulasminingsih, (2006). Kebiasaan Makan Pagi, Status Gizi dan Prestasi Belajar di SDN Koroulon 1 Bimomartani Ngemplak Sleman, program Sarjana UGM

Soekirman, (2000). IImu Gizi dan Aplikasi untuk Keluarga dan Masyarakat, Jakarta:Direktorat Jendral Pendidikan Tinggi Departemen Pendidikan Nasional

Syah, M., (2001). Psikologi Belajar. PT Raja Grafindo Persada. Jakarta

Wilma, (2006). Hubungan Status Gizi Dengan Prestasi belajar Anak Sekolah Dasar Di Kabupaten Nabire 